\title{
FILSAFAT RASIONALISME
}

\author{
Andi Arsi ${ }^{1}$, Wa Ode Nurfitri Fail ${ }^{2}$, \\ Dosen Pembimbing : Ibnu Hajar Sainuddin ${ }^{3}$
}

${ }^{1}$ Sekolah Tinggi Agama Islam (STAI) Darul Dakwah Wal-Irsyad (DDI) Kota Makassar, Indonesia Email: arsia3739@gmail.com

${ }^{2}$ Sekolah Tinggi Agama Islam (STAI) Darul Dakwah Wal-Irsyad (DDI) Kota Makassar, Indonesia Email: waodenurfitrifail@gmail.com

${ }^{3}$ Sekolah Tinggi Agama Islam (STAI) Darul Dakwah Wal-Irsyad (DDI) Kota Makassar, Indonesia Email: ibnuhajar@staiddimakassar.ac.id

\begin{abstract}
ABSTRAK
Rasionalisme ialah faham filsafat yang menyatakan bahwa akal (reason) adalah alat terpenting untuk memperoleh pengetahuan dan menetes pengetahuan. Rasionalisme percaya bahwa cara untuk mencapai pengetahuan adalah menyandarkan diri pada sumber daya logika dan intelektual. Penalaran demikian tidak berdasarkan pada data pengalaman, tetapi diolah dari kebenaran dasar yang tidak menuntut untuk menjadi dan mendasarkan diri pada pengalaman. Pengalaman indera diperlukan untuk merangsang akal dan memberikan bahanbahan yang menyebabkan akal dapat bekerja. Akan tetapi, untuk sampainya manusia kepada kebenaran, adalah semata-mata dengan akal.
\end{abstract}

\section{Kata Kunci : Filsafat, Rasionalisme, Akal}

\section{A. PENDAHULUAN}

Rene Descartes yang mendirikan aliran rasionalisme ini berpendapat bahwa sumber pengetahuan yang dapat dipercaya adalah akal. Hanya oengetahuan yang diperoleh lewat akallah yang memenuhi syarat yang dituntut oleh semua ilmu pengetahuan ilmiah. Dengan akal, dapat diperoleh kebenaran dengan metode deduktif, seperti yang dicontohkan dalam ilmu pasti. Ada anggapan bahwa kaum rasionalis adalah sebagai filosof yang mengawangawang tidak seluruhnya salah, karena pendekatan mereka kepada filsafat menyarankan bahwa seluruh kebenaran penting tentang realitas bisa ditemukan hanya dengan berpikir, tanpa kebutuhan untuk berangkat dan menguji dunia. Rasionalisme bisa memunculkan sedikit bintik pada pikiran modern, yang digunakan untuk ide bahwa pengatahuan yang menekankan diri pada percobaan dan pengamatan, adalah penting untuk mengetahui selanjutnya. Oleh karena itu, dalam tulisan ini sangat penting kiranya untuk diulas secara mandalam tentang bagaimana corak pemikiran rasionalisme sebagai bagian aliran dari epistemologi filsafat, bagaimana cara kerjanya, metodenya, siapa saja tokohnya dan apa saja pemikiran yang dihasilkan. ${ }^{1}$

\section{B. PEMBAHASAN}

\section{Etika Perspektif Filsafat Islam}

Rasionalisme adalah faham filsafat yang menyatakan bahwa akal (reason) adalah alat terpenting untuk memperoleh pengetahuan dan menetes pengetahuan. Jika empirisme mengatakan bahwa pengetahuan diperoleh dengan alam mengalami objek

${ }^{1}$ Asmoro Akhmadi, Filsafat Umum, (Jakarta: Raja grafindo Persada, 2007), h. 115 
empiris, maka rasionalisme mengajarkan bahwa pengetahu an diperoleh dengan dengan cara berpikir. Alat dalam berpikir itu adalah kaidah-kaidah logis atau aturanaturan logika. Rasionalisme tidak mengingkari kegunaan indera dalam memperoleh pengetahuan. Pengalaman indera diperlukan untuk merangsang akal dan memberikan bahan-bahan yang menyebabkan akal dapat bekerja. Akan tetapi, untuk sampainya manusia kepada kebenaran, adalah semata-mata dengan akal. Laporan indera menurut rasionalisme merupakan bahan yang belum jelas dan kacau. Bahan ini kemudian dipertimbangkan oleh akal dalam pengalaman berpikir. Akal mengatur bahan itu sehingga dapatlah terbentuk pengetahuan yang benar. Akal dapat bekerja dengan bantuan indera, tetapi akal juga dapat menghasilkan pengetahuan yang tidak berdasarkan bahan inderawi sama sekali, jadi, akal dapat menghasilkan pengetahuan tentang objek yang betul-betul abstrak. ${ }^{2}$

Sejarah rasionalisme sudah tua sekali, pada zaman Thales (624-546 SM) telah menerapkan rasionalisme pada filsafatnya. Rasionalisme lahir adalah sebagai reaksi terhadap dominasi Gereja pada Abad Pertengahan Kristen di Barat. Munculnya rasionalisme ini menandai perubahan dalam sejarah filsafat, karena aliran yang dibawa Descartes ini adalah cikal bakal Zaman Modern dalam sejarah perkembangan filsafat. Kata modern disini hanya digunakan untuk menunjukkan suatu filsafat yang mempunyai corak yang amat berbeda, bahkan berlawanan dengan corak filsafat pada Abad Pertengahan Kristen. Corak berbeda yang dimaksud disini adalah dianutnya kembali rasionalisme seperti pada masa Yunani Kuno. Gagasan itu disertai argumen yang kuat oleh Descartes. Oleh karena itu, pemikiran Descartes sering juga disebut bercorak renaissance, yaitu kebangkitan rasionalisme seperti pada masa Yunani terulang kembali. Pengaruh keimanan Kristen yang begitu kuat pada Abad Pertengahan, telah membuat para pemikir takut mengemukakan pemikiran yang berbeda dengan tokoh Gereja. Descartes telah lama merasa tidak puas dengan perkembangan filsafat yang sangat lamban dan memakan banyak korban. Ia melihat tokoh-tokoh Gereja yang mengatasnamakan agama telah menyebabkan lambannya perkembangan itu. Ia ingin filsafat dilepaskan dari dominasi agama Kristen. Ia ingin filsafat dikembalikan pada semangat filsafat Yunani, yaitu filsafat yang berbasis pada akal. $^{3}$

Agar filsafat dan ilmu pengetahuan dapat diperbaharui, kita memerlukan metode yang baik, demikian pendapat Descartes (tokoh utama rasionalisme). Descarters sudah menemukan metode yang dicarinya, yaitu dengan menyangsikan segala-galanya, atau keragu-raguan. Kemudian, ia menjelaskan, untuk mendapatkan hasil yang sahih dari metode yang hendak dicanangkannya, ia menjelaskan perlunya dalam empat hal yaitu sebagai berikut :

${ }^{2}$ Ahmad Tafsir, Filsafat Umum; Akal dan Hati Sejak Thales Sampai Capra, hlm. 25

${ }^{3}$ Ahmad Tafsir, Filsafat Umum; Akal dan Hati Sejak Thales Sampai Capra, hlm. 128-129 
1) Tidak menerima sesuatu pun sebagai kebenaran, kecuali bila saya melihat bahwa hal itu sungguh-sungguh jelas dan tegas, sehingga tidak ada suatu keraguan apapun yang mampu merobohkannya.

2) Pecahkanlah setiap kesulitan atau masalah itu atau sebanyak mungkin bagian, sehingga tidak ada keraguan apapun yang mampu merobohkannya.

3) Bimbangkanlah pikiran dengan teratur, dangan mulai dari hal yang sederhana dan mudah diketahui, kemudian secara bertahap sampaipada yang paling sulit dan kompleks.

4) Dalam proses pencarian dan pemeriksaan hal-hal sulit, selamanya harus dibuat perhitungan-perhitungan yang sempurna serta pertimbanganpertimbangan yang menyeluruh, sehingga kita yakin tidak ada satu pun yang diabaikan dalam penjelajahan itu. ${ }^{4}$

\section{Pemikiran Tokoh-Tokoh Rasionalisme}

* Rene Descartes (1596-1650)

Rene Descartes (Renatus cartesius) adalah putra keempat Joachim Descartes, seorang anggota parlemen kota britari, propinsi renatus di prancis. Kakeknya, piere Descartes, adalah seorang dokter. Neneknya juga berlatar belakang kedokteran, dilahirkan pada tanggal 31 Maret 1596 di La Haye (sekarang disebut La Haye Descartes), propinsi Teuraine. Descartes kecil yang mendapat nama baptis Rene, tumbuh sebagai anak yang menampakan bakatnya dalam bidang filsafat, sehingga ayahnya pun memanggilnya dengan julukan Si Filsuf Cilik. Pendidikan pertamanya diperoleh dari sekolah Yesuit di La Fleche dari tahun 1604-1612. Disinilah ia memperoleh pengetahuan dasar tentang karya ilmiah Latin dan Yunani, bahasa Prancis, music dan acting, logika aristoteles dan Etika Nichomacus, fisika, matematika, astronomi dan ajaran metafisika dari filsafat Thomas Aquinas.

Metode Kesangsian dan "Cogito Ergo Sum” Untuk memperoleh titik kebenaran pengetahuan, Descartes mulai dengan esebuah kesangsian atas segala sesuatu. Menurut Dascartes, sekurang-kurangnya aku yang menyangsikanll bukanlah hasil tipuan. Semakin kita dapat menyangsikan segala sesuatu, entah kita sungguh ditipu atau ternyata tidak, termasuk menyangsikan bahwa kita tidak dapat menyangsikan, kita semakin mengada (exist). Justru kesangsianlah yang membuktikan kepada diri kita bahwa kita ini nyata. Selama kita ini sangsi, kita akan merasa semakin pasti bahwa kita nyata-nyata ada. Jadi, meski dalam tipuan yang lihai, kepastian bahwa aku yang menyangsikan itu ada tidak bisa 18 dibantah. Menyangsikan adalah berpikir, maka kepastian akan eksistensiku dicapai dengan berpikir. Descartes kemudian mengatakan Je pense donce je suis atau cogito ergo sum (aku berpikir, maka aku ada $)^{5}$

\section{* Baruch De Spinoza (1632-1677)}

Kelahiran Spinoza dilahirkan pada tahun 1632 dan meninggal dunia pada tahun 1677 M. Nama aslinya Baruch Spinoza. Setelah ia mengucilkan diri dari agama Yahudi, ia mengubah namanya menjadi Benedictus de Spinoza. Ia hidup di pinggiran kota Amsterdam. Tentang Pengetahuan Menurut Spinoza, ada tiga taraf pengetahuan, yaitu berturut-turut: taraf

${ }^{4} J u h a y a$ S. Praja, Aliran-Aliran Filsafat dan Etika, (Jakarta: Kencana, 2003), Cet. 2, h. 95-96

${ }^{5}$ F. Budi Hardiman, Pemikiran-Pemikiran yang Membentuk Dunia Modern, (Jakarta: Erlangga, 2010), h. 33-34 
persepsi indrawi atau imajinasi, taraf refleksi yang mengarah pada prinsip-prinsip dan taraf intuisi. Hanya taraf kedua dan ketigalah yang dianggap pengetahuan sejati. Dengan ini, Spinoza menunjukkan pendiriannya sebagai seorang rasionalis. Pendiriannya dapat dijelaskan demikian, menurutnya sebuah idea berhubungan dengan ideatum atau obyek dan kesesuaian antara idea dan ideatuminilah yang disebut dengan kebenaran. Dia membedakan idea ke dalam dua macam, yaitu idea yang memiliki kebenaran intrinsik dan idea yang memiliki kebenaran ekstrinsik. Idea yang benar secara intrinsik menurutnya memiliki sifat memadai, sedangkan idea yang benar secara ekstrinsik disebutnya kurang memadai.

\section{* Leibniz (1646-1716)}

Kelahiran Leibniz lahir di Jerman, nama kengkapnya Gottfried Wilhem von Leibniz. Sama halnya Spinoza, Leibniz termasuk pengagum sekaligus pengkritik Descartes. Baginya, ia khawatir tentang kehidupan dan bagaimana menjalani hidup. Tetapi berbeda dengan Spinoza yang kesepian, ia justru termasuk orang yang kaya raya dan dipuja. Leibniz juga dikenal sebagai penemu kalkulus bersama Newton. Ia adalah ilmuan, pengacara, sejarawan, akademisi, ahli logika, ahli bahasa, dan teolog. Bagi Leibniz, filsafat adalahhobi yang berkesinambungan dan ia terlibat dalam diskusi filosofis dan melakukan korespondensi sepanjang hidupnya bersama para filsuf di zamnnya. Sayangnya, karyanya tidak bisa dinikmati banyak orang, karena setelah ia meninggal, karyanya tidak diterbitkan. ${ }^{6}$

Pemikiran Leibniz yang terkenal adalah monadologinya, dia berpendapat bahwa banyak sekali subtansi yang terdapat di dunia ini, yang disebutnya "monad" Monad ini semacam cermin yang membayangkan kesempurnaan yang satu itu dengan caranya sendiri. Tiap-tiap pencerminan yang terbatas ini mengandung kemungkinan tidak terbatas karena dalam seluruhnya dapat diperkaya dan dipergandakan oleh sesuatu dari sesuatu yang mendahuluinya. Dalam rentetan ini ada tujuan yang terakhir, yaitu menuju yang tak terbatas sesungguhnya. Tuhan itu transendent, artinya Tuhan di luar makhluk, Tuhan merupakan dasar dari segala rentetan yang ada. ${ }^{7}$

Adapun salah satu ulama sufi dan pemikir mistik teosof yang banyak mengajarkan tentang etika dan filsafat adalah Syekh Muhammad Yusuf Al-makassari.Ia merupakan salah satu dan dan juga pahlawan yang dalam perjuangannya menyebarkan agama Islam menjadi tonggak bersejarah bagi seorang putra di daerah Gowa.Konsep etika dan moral dari ajaran Syekh Yusuf secara substantif berbasis pada prinsip”Al takhalluq bi akhlaq Allah” (berakhlak dengan akhlak Allah). Etika yang di ajarkan sufi seperti syekh yusuf bersifat komprehensif, substantif dan universal. Syekh yusuf sendiri berkali-kali menekankan perlunya menerapkan "husnul khuluk" akhlak luhur baik terhadap tuhan maupun makhluk. Akhlak yang baik haruslah bersifat utuh,lengkap dan tercermin dalam seluruh penampilan pribadi seseoarang yang mencakup, perkataan, perbuatan yang timbul dari hati yang bersih, serta sifat dan sikap. ${ }^{8}$

${ }^{6}$ Ali Maksum, Pengantar Filsafat; Dari Masa Klasik hingga Postmodernisme, (Yogyakarta: Arruzz Media, 2008), Cet. 1, h. 131-132

${ }^{7}$ Poedjawijatna, Pembimbing ke Arah Filsafat, (Jakarta: Rineka Cipta, 1997), Cet. 10, h. 103.

${ }^{8}$ Sainuddin, Ibnu Hajar, and Ismail Suardi Wekke. "Syekh Yusuf AlMakassari: Pandangan Etika

dan Filsafat." (2020), hlm. 1. \& Mustari, Belajar Etika Kepada Syekh Yusuf Al-Makassari,(2020).hlm.145 


\section{PENUTUP}

Rasionalisme adalah faham filsafat yang menyatakan bahwa akal (reason) adalah alat terpenting untuk memperoleh pengetahuan dan menetes pengetahuan. Jika empirisme mengatakan bahwa pengetahuan diperoleh dengan alam mengalami objek empiris, maka rasionalisme mengajarkan bahwa pengetahuan diperoleh dengan dengan cara berpikir. Alat dalam berpikir itu adalah kaidah-kaidah logis atau aturan-aturan logika.

Adapun Beberapa Pemikiran para Tokoh Rasionalisme yaitu sebagai berikut :

1) Rene Descartes (1596-1650), yaitu, sumber pengetahuan yang dapat dipercayai adalah akal.

2) Baruch De Spinoza (1632-1677), yaitu sebuah idea berhubungan dengan ideatum atau obyek dan kesesuaian antara idea dan ideatuminilah yang disebut dengan kebenaran.

3) Leibniz (1.646-1716 M), Pemikiran Leibniz yang terkenal adalah monadologinya, dia berpendapat bahwa banyak sekali subtansi yang terdapat di dunia ini, yang disebutnya “monad” (monos:satu, monad: satu unit)

\section{DAFTAR PUSTAKA}

Sainuddin, Ibnu Hajar, and Ismail Suardi Wekke. "Syekh Yusuf Al-Makassari: Pandangan Etika dan Filsafat." (2020).

Sainuddin, Ibnu Hajar, Muhammad Arsyam, and Ismail Suardi Wekke. "Syekh Yusuf AlMakassari; Pengembangan Masyarakat Islam.” (2020)

Sainuddin, Ibnu Hajar, and Ismail Suardi Wekke. "Islamisasi Kerajaan Gowa." (2020).

Arsyam, Muhammad,and Ibnu Hajar Sainuddin.”Meraih Surga dengan Sabar dan Syukur.”

Sainuddin, Ibnu Hajar, Muhammad Arsyam, and Andi Muhammad Shaleh Alwi. "Pemahaman Makna Tauhid dan Dua Kalimat Syahadat." (2020).

Praja, Juhaya S. Aliran-aliran filsafat \& etika. Prenada Media, 2020.

Nurohman, Muhamad Agus. "Rasionalisme dan Empirisme Dalam Filsafat Ontologi." Jurnal

Dewantara 9.01 (2020): 19-34. Handayani, Silvana Liz. "Sumber Pengetahuan (FILSAFAT ILMU)." (2020). Arifin, Mochammad. "EPISTEMOLOGI RASIONALISME RENE DESCARTES DAN RELEVANSINYA TERHADAP PENAFSIRAN AL-QURAN." Jurnal Ilmiah Ilmu Ushuluddin 17.2 (2018): 147-157.

Riyadi, Agus, and Helena Vidya Sukma. "Konsep Rasionalisme Rene Descartes Dan Relevasinya Dalam Pengembangan Ilmu Dakwah." An-Nida: Jurnal Komunikasi Islam 11.2 (2019).

Fikri, Mursyid. "Rasionalisme Descartes dan Implikasinya Terhadap Pemikiran Pembaharuan Islam Muhammad Abduh." TARBAWI: Jurnal Pendidikan Agama Islam 3.02 (2018): 128-144. 
Kariarta, I. Wayan. "Filsafat Ketuhanan Menurut Baruch de Spinoza." Genta Hredaya: Media Informasi Ilmiah Jurusan Brahma Widya STAHN Mpu Kuturan Singaraja 4.2 (2020): 124-134.

Teng, Muhammad Bahar Akkase. "Raionalis dan Rasionalisme dalam Perspektif Sejarah”. Jurnal Ilmu Budaya (2016). 